cognitive şi factorii de personalitate descriu cel mai bine eficacitatea şi performanța organizațională decizională. Pe de altă parte, în condiții de stabilitate, aptitudinile cognitive generale şi dimensiunile de personalitate sunt predictori ai performanței decizionale. Acest capitol realizează o integrare bine structurată a premiselor de la care s-a pornit cu rezultatele cercetărilor realizate, implicațiile pentru practicieni fiind de asemenea relevate.

Având în vedere aspectele teoretice, de cercetare şi recomandări pentru practicenii din domeniul psihologiei organizaționale, cartea este un material util pentru studenți, prin prezentarea unei analize complexe a teoriilor şi modelelor din psihologia organizațională centrate pe decizie şi schimbare organizațională, pentru doctoranzi şi cercetători în domeniu, prin descrierea detaliată a unor strategii şi metodologii de cercetare, şi nu în ultimul rând pentru practicieni, deoarece analizele teoretice prezentate, analiza critică a modelelor din literatura de specialitate precum şi rezultatele practice ale studiilor prezentate relevă implicații valoroase pentru provocările concrete ale realității organizaționale, în domeniul selecției şi evaluării de personal, diagnozei şi intervenției organizaționale.

Cartea Deliei Vîrgă se remarcă în literatura de specialitate autohtonă pentru că tema abordată este una de extremă actualitate în România; îmbinarea aspectelor teoretice cu cele de cercetare, relevarea unor strategii şi sugestii specifice pentru practicieni, reprezintă o „invitație academică” greu de refuzat.

Coralia Sulea

\section{Eugen Avram (Editor) (2008). Psychology in a Positive World. Resources for Personal, Organizational, and Social Development. Bucureşti: Editura Universității din Bucureşti (376 pagini)}

Ramură relativ nouă a ştiinței, psihologia pozitivă are ca principal obiectiv studiul potențialului uman, al prosperității umane. În acest context, aspectele investigate sunt atitudinile, mecanismele intrinseci care stau la baza procesului de evoluție a individului, a autorealizării lui şi implicit la baza sănătății sale psihologice. Totodată, psihologia pozitivă încearcă să desluşească tainele unei viziuni pozitive asupra vieții, secretele unui scenariu de viață câştigător. Literatura de specialitate abundă în studii care subliniază rolul atitudinilor individului față de sine şi față de lume în reglarea modului său de raportare la evenimentele de viață pe care le experimentează, la calitatea vieții pe care o trăieşte.

Înscriindu-se în aria psihologiei pozitive, acest volum reuneşte lucrările a diverşi cercetători, profesori, practicieni de renume, focalizați pe aspecte esențiale pentru dezvoltarea resurselor umane. Cartea cuprinde trei mari părți, fiecare oferind o perspectivă pozitivă asupra resurselor necesare pentru dezvoltarea personală a individului, dezvoltarea organizațională şi a societății în ansamblu.

Capitolele care alcătuiesc prima parte a colecției tratează problematica profilului caracterial al individului bun, moral şi implicațiile acestui profil pentru psihologia organizațională, psihologia clinică şi psihoterapie, psihopatologie, psihologie socială, psihologia dezvoltării. Eugen Avram discută pe rând caracteristicile profilului caracterial bun care ar sta la baza unor comportamente, norme, valori care construiesc o societate ideală în care oamenii experimentează nivele crescute de bunăstare psihologică şi satisfacție cu viața. Irina Holdevici, într-un studiu următor, se centrează asupra fenomenului de gândire pozitivă, asupra atitudinilor şi credințelor persoanei. Este discutat modul în care propria viziune a individului reprezintă 0 resursă pentru dezvoltarea lui personală. Din perspectiva terapiei cognitiv-comportamentale sunt trecute în revistă o serie de strategii prin care individul poate regla viziunea sa despre sine şi lume în aşa fel încât aceasta să contribuie la dezvoltarea sa. Ana Frichand, autoarea celui de-al treilea capitol din prima parte a cărții, se opreşte asupra adolescenței - moralitatea şi valorile pe care generația de astăzi le are ca model în contextul schimbărilor pe care instituția de bază a societății, familia, le traversează. Este adus în prim plan subiectul crizei morale caracteristică societății de astăzi şi implicațiile acestei realități pentru dezvoltarea adolescentului care trăieşte într-o lume haotică (Szentmartoni, 2004). Autoarea invocă modelele parentale, figuri marcante din viața adolescenților (profesori, politicieni etc.) cu o conduită morală, consecventă, drept o posibilă soluție pentru remedierea acestei situații.

Capitolul patru abordează problematica predispoziției de a crede în 
adevărul spuselor celorlalți cu care relaționăm. Rezultatele studiului trec în revistă rolul diferențelor individuale în studiul credibilității. Laurențiu Mitrofan, în capitolul cinci, tratează problematica prieteniei văzută ca 0 „cale de dezvoltare şi maturizare a personalității”. Comportamentul de prietenie include altruismul, dorința de a ajuta, empatia, simpatia, sentimente împărtăşite şi de altă persoană. Formarea şi restructurarea imaginii de sine este strâns legată de interacțiunile sociale pe care le avem de-a lungul vieții. Prietenia este un fenomen social care ajută la formarea şi restructurarea sinelui tocmai prin interactiunea $\mathrm{cu}$ celălalt, vitală pentru conturarea individualității fiecăruia dintre noi. Este un teren complex care facilitează interacțiunea umană, unde indivizii experimentează manipularea, supunerea dar şi ataşamentul emoțional, iubirea, apropierea, compararea socială, toate aceste realități contribuind la definirea sinelui şi conturarea identității de sine. Autorii ultimului capitol din prima parte a cărții se opresc tot pe teritoriul relațiilor umane, analizând paternuri relaționale care apar în interacțiunile de familie, cuplu sau prietenie. Modul în care copilul se raportează la lume şi construieşte relația emoțională cu părinții va constitui baza relațiilor sale viitoare. Schemele relationale devin comportamente automate, inconştiente pe care individul le practică în relațiile sale viitoare.

Partea a doua a cărții se centrează asupra resurselor pentru dezvoltarea organizațională. În primul capitol, Eugen Avram şi Carmen Chiru se opresc asupra unor dimensiuni esențiale pentru viața organizațională: încrederea organizațională (cu latura ei cognitivă şi afectivă), colaborarea, credințele oamenilor referitoare la viața din organizație care facilitează colaborarea şi performanța la locul de muncă. După cum afirmă autorii, încrederea, face parte din arhitectura individuală şi organizațională, este o fundatie pe care se pot construi relatiii solide. Acest studiu subliniază importanța încrederii ca resursă importantă în viața unei organizații.

Emilie Boujut, în capitolul următor investighează antecedentele psihosociale ale reuşitei universitare. Autoarea studiază rolul variabilelor cognitive (inteligența, stilul de învățare), precum şi relația dintre dimensiunile de personalitate (cei cinci factori specificați în modelul Big Five) şi performanțele academice. Alți factori de personalitate asupra cărora autoarea se opreşte în studiul său se referă la afectivitatea pozitivă, afectivitatea negativă, stima de sine, optimismul, încrederea în sine, sentimentul autoeficienței personale. Toate acestea, alături de suportul social şi anumite strategii sănătoase de adaptare constituie resurse importante pentru reuşita academică.

Plecând de la teoria lui Bandura (1986) asupra autoeficacității personale, în capitolul următor, Enrique Merino Tejedor proiectează o serie de strategii, programe de intervenție menite să îmbunătățească percepția asupra sentimentului autoeficacității personale şi, implicit, performanțele din viața profesională a individului.

O altă realitate din viața organizațională, cu implicații asupra sănătății psihologice a individului este autodezvăluirea, fenomen care se petrece pe teritoriul interacțiunilor cu celălalt. Autorul, Răzvan G. Zaharia, trece în revistă mecanismele psihice ale autodezvăluirii, principalii predictori ai acestui fenomen şi relația lui cu sănătatea psihologică şi adaptarea socială a individului.

Capitolul următor sintetizează o serie de aspecte caracteristice societății nigeriene privind utilizarea resurselor (resurse financiare, resursele umane, resurse fizice) în şcolile generale, precum şi implicațiile acestor stări de fapt asupra sistemului de educație.

Valentin Dinu investighează în cadrul studiului său problematica stresului în diferite structuri organizaționale, accentuând tematica stresului în organizațiile birocratice. Premisa de la care se pleacă este că performanțele crescute sunt atât rezultatul resurselor investite dar şi al unei forme eficiente de organizare. Rezultatele studiului evidențiază consecințele structurii birocratice asupra satisfacției angajaților şi randamentului organizațional.

În următorul capitol, Răzvan Stan contribuie la diversitatea acestui volum prin studiul său intitulat „Spiritul culturii profesionale a minerilor", care reprezintă o incursiune în cultura profesională a minerilor. Autorul trece în revistă valorile profesionale, câteva mituri din lumea minei, schițând totodată şi profilul psihologic al minerului, comportamentul revendicativ al acestuia, relațiile sociale în afara muncii. De asemenea, este conceput şi un tablou al culturii profesionale a minerilor, între unitate şi diversitate.

Partea a treia a volumului, „Resurse pentru dezvoltarea socială" abordează punctual într-un prim capitol problematica metodelor statistice utilizate în studiul reciprocității în interacțiunile sociale (cooperarea). În capitolul următor, Ricardo 
Garcia Mira prezintă un studiu amplu despre incendiile forestiere din Regiunea Autonomă a Galiciei (Spania) în vederea stabilirii unor politici, programe de acțiune menite să prevină astfel de pericole. În prevenirea acestor dezastre, este subliniat rolul important al unei strategii bine definite de comunicare socială. Rezultatele cercetării evidențiază percepția socială asupra incendiilor din vara anului 2006, modul în care eşantionul investigat atribuie cauze şi responsabilități legate de aceste dezastre.

Pornind de la afirmația lui Dafinoiu conform căreia realitatea este o iluzie, Mihai Zota conturează reprezentarea socială a conceptului de „cetățean român” şi „cetățean occidental". Autorul surprinde modul în care românii înțeleg şi îşi reprezintă valorile europene pe care teoretic şi le-au asumat. "Libertatea” este un element definitoriu al reprezentării conceptului de european iar elementul „prosperitate” defineşte reprezentarea socială a occidentalului. După cum însuşi autorul afirmă, „studiul de față relevă o asumare autentică a valorilor europene de către români."

Capitolul următor prezintă un studiu realizat pe zece categorii sociale din Bulgaria. Sunt investigate aspecte ale dezvoltării personalității din punct de vedere al dimensiunilor extraversie, neuroticism, psihoticism şi dezirabilitate socială. Rezultatele studiului subliniază existența unor diferențe pe aceste dimensiuni în funcție de variabilele gen, vârstă şi ocupație de bază.

Ligia Tătăranu, în studiul său „Integrarea socio-profesională a persoanelor cu sechele după traumatisme craniocerebrale" aduce în discuție categoria persoanelor cu traumatisme craniocerebrale. Sunt punctate aspectele psihologice studiate în relație $\mathrm{cu}$ acest tablou clinic, principalele strategii de reabilitare neuropsihologică din perspectiva psihoterapeutului şi principiile pedagogice care pot fi aplicate în vederea creșterii calității vieți acestor indivizi şi sensibilizării societății față de persoanele cu un astfel de handicap.

Simona Glăveanu abordează problema dezvoltării abilităților sociale la elevi. În perspectiva autoarei, abilitățile emoționale, sociale sunt resurse esențiale pentru succesul şcolar şi cel din viața de zi cu zi. Studiul subliniază rolul decisiv al părinților şi al cadrelor didactice în educarea atitudinilor şi implicit conduitelor prosociale la copii. Sunt trecute în revistă o serie de practici parentale şi didactice, metode moderne pe care autoarea le recomandă ca utile în vederea dezvoltării acestor abilități.

Eugen Avram şi Claudia Radu încheie această colectie de studii cu un articol interesant care pledează pentru educația caracterului într-o societate pozitivă. Este subliniat rolul important al "agenților" responsabili de educarea caracterului: familia, comunitatea, societatea. Autorii prezintă principiile şi dimensiunile majore ale educării caracterului (valorile, judecățile morale, conduitele prosociale), aspecte teoretice importante care îşi pot găsi aplicabilitate în programe punctuale destinate elevilor din şcoli şi licee, menite să reprezinte ghiduri pentru o educație centrată pe dezvoltarea socială.

Această colecție de studii, prin diversitatea şi actualitatea subiectelor abordate reprezintă un material captivant şi de interes pentru toți cei interesați de dezvoltarea personală, organizațională şi a societății în ansamblu.

Roxana Vaida

\section{Marian Popa (2008). Introducere în psihologia muncii. laşi: Editura Polirom (309 pagini)}

Aşa cum autorul subliniază încă din introducere, cartea de față are un caracter introductiv tratând unele dintre cele mai importante teme ale psihologiei muncii: analiza psihologică a muncii, evaluarea performatelor în muncă, relația om-maşină-mediu, selecția personalului, solicitarea profesională, oboseala etc.

Cartea „Introducere în psihologia muncii" este structurată pe 10 capitole având un solid fundament bibliografic şi ştiințific. În introducere autorul prezintă un scurt istoric al psihologiei muncii care este ca un elogiu adus muncii de-a lungul timpului: „ansamblul conduitelor umane, fizice şi intelectuale supuse unor exigențe de organizare, a căror finalitate este orientată spre propriul beneficiu şi/sau al altora".

„Analiza psihologică a muncii”, prezentată în cel de-al doilea capitol, vine în ajutorul celor care se află la începutul desluşirii tainelor analizei muncii orientată pe postul de muncă (Job Description) şi pe deținătorul postului de muncă (Job Specification). De asemenea, în acest capitol este trecută în revistă clasificarea ocupatịilor prezentată 